Pregledni znanstveni rad DOI: $10.17234 /$ Croatica.42.7 UDK: 811.163.42'35Pranjković, I. Primljen: 18. XI. 2017. Prihvaćen: 25. I. 2018.

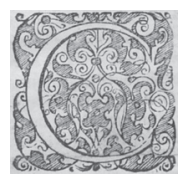

\title{
PRANJKOVIĆ O PRAVOPISU
}

\author{
Lada Badurina \\ Filozofski fakultet Sveučilišta u Rijeci \\ Odsjek za kroatistiku \\ lbadurin@ffri.hr
}

U većem se broju svojih tekstova Ivo Pranjković zanima za pravopisne teme. Među njima ima relativno neutralnih članaka u kojima se razmatraju pojedina pravopisna pitanja, kritički intoniranih prikaza, ali i vrlo oštrih polemičkih utuka. Svima je njima zajedničko autorovo jasno iskazivanje stavova i dosljednost $u$ argumentacijskim postupcima. U ovom ćemo se prilogu s jedne strane osvrnuti na sadržajnu stranu Pranjkovićevih tekstova o pravopisu i na njegove pravopisne nazore, dok će s druge strane biti riječi o značajkama Pranjkovićeva stila, napose o njegovoj polemičnosti.

Ključne riječi: Ivo Pranjković, pravopis, polemika, znanstveni tekst, akademski diskurs

\section{UVOD: O DVOJAKOJ MOTIVACIJI ZA OVU TEMU}

Iako, po vlastitu priznanju, Ivo Pranjković nije osobito zaokupljen pravopisnim temama, svaki bolji poznavatelj hrvatskih pravopisnih (ne)prilika u zadnjih tridesetak godina nije mogao zaobići njegove članke i o odabranim pravopisnim problemima i o pojedinim pravopisnim knjigama (priručnicima). Ovaj bi se prilog s jedne strane mogao stoga shvatiti kao svojevrsna inventura autorovih zapisa o hrvatskom pravopisu i kao osvrt na njegove pravopisne nazore. No to je ipak samo jedan aspekt ove teme. Drugi - čini 
nam se i poticajniji - onaj je koji se tiče forme prije negoli sadržaja Pranjkovićevih napisa o pravopisu. Naime nemoguće je ne zamijetiti da su oni dominantno polemički intonirani, da su (kao takvi) nerijetko provocirali polemičke okršaje ili su, štoviše, i pisani kao polemički utuci. U tom smislu (i) ovim svojim tekstom nastavljamo temu započetu prije desetak godina - i tada u zborniku u čast Ivi Pranjkoviću - naime onu o Pranjkovićevoj polemičnosti i njegovim polemikama, odnosno - u krajnjoj konsekvenci - o polemičnosti i polemikama u našem akademskom (ili znanstvenom) prostoru (usp. Badurina 2010).

Dvojaka motiviranost najavljene teme ogledat će se dakle i u ovome ogledu. Uz podsjećanje na Pranjkovićeve tekstove o pravopisnim temama (i pokušaj njihove sistematizacije) novo će težište ovoga rada biti na nekim stilskim značajkama (ako ne svih, onda barem većega dijela) tih tekstova, napose na njihovoj polemičnosti (pri čemu će se nastojati rasvijetliti ključni indikatori polemike/polemičnosti, posebice u onim tekstovima koji primarno nisu bili zamišljeni kao polemike). Naposljetku bit će to prigoda da se aktualizira još jedno važno pitanje - pitanje je to jezika (ili, bolje: komunikacije) u znanosti. U tom će se kontekstu, smatramo, morati u konačnici sagledavati - pa, možda, i ozbiljnije propitati - koncept znanstvenoga funkcionalnog stila, koji nasljeđujemo od praške funkcionalne stilistike.

\section{PRANJKOVIĆ KAO KRONIČAR HRVATSKIH PRAVOPISNIH ZBIVANJA}

Pranjkovićevi tekstovi koji se bave pravopisnom problematikom ugrubo se mogu podijeliti u dvije skupine. U prvu ćemo uvrstiti one koji su pisani u povodu objavljivanja pojedinih pravopisnih knjiga (priručnika). To su uglavnom prikazi, kritike i/ili osvrti na ta izdanja. U drugoj su se skupini našli raznovrsni tekstovi: neki se od njih tiču važnijih pravopisnih problema (npr. sastavljeno/nesastavljeno pisanje, pitanje tzv. dvoglasnika), drugi su neposredne reakcije na aktualne pravopisne nedoumice, odnosno na nerijetko i dramatična zbivanja u vezi s hrvatskim pravopisom. U drugoj je skupini, očekivano, više (eksplicitno) polemičkih tekstova.

$* * *$

Konkretno, Pranjković je u nepunih desetak godina u periodici kritičkim osvrtima popratio pojavljivanje čak četiriju pravopisnih izdanja, $\mathrm{i}$ to redom: 
Anić-Silićeva Pravopisnog priručnika hrvatskoga ili srpskoga jezika (1987b), Osnova pravilnoga pisanja Domagoja Grečla (1987a), Cipra-Klaićeva Hrvatskoga pravopisa iz 1944, čiji je pretisak objavljen 1992 (1993a), te napokon i novoga, promijenjenoga izdanja Babić-Finka-Moguševa Hrvatskoga pravopisa iz 1994. godine (1995). Time je on nesumnjivo dokazao zainteresiranost za aktualnu hrvatsku pravopisnu situaciju, pa onda i osobnu angažiranost u njezinu tumačenju!

Anić-Silićev Pravopisni priručnik, prvi koji je Pranjković prikazao - a ne treba smetnuti s uma da je to i prva u Hrvatskoj objavljena pravopisna knjiga nakon novosadskoga pravopisa - dobio je prikazivačevu iznimno visoku ocjenu. Kao najveću kvalitetu ovoga pravopisa istaći će on to što se u Priručniku "od početka do kraja, gotovo maksimalno, poštuju načela logičnosti i dosljednosti" te će u tom kontekstu posebno izdvojiti problematiku sastavljenoga i nesastavljenoga pisanja, onu po kojoj se - po njegovu sudu - ta knjiga najviše udaljila od novosadske (Pranjković 1993: 107-108). ${ }^{1}$ Posebno on nadalje cijeni to što je taj pravopis oslobođen onoga što mu načelno ne pripada, što u njemu "nema elemenata gramatičkog ili leksičkog opisivanja ili propisivanja, nema podataka etimološke naravi i sl.” (1993: 108). Ne zanemaruje međutim Pranjković važnost pravopisnog kontinuiteta pa posebno naglašava da su autori Priručnika "vodili [...] računa o pravopisnoj tradiciji u nas kad god to nije bilo u neskladu s metodološkim načelima njihova pristupa" (1993: 110). Načelno pozitivna ocjena pravopisne knjige ne znači, dakako, da Pranjković nema i pokoju kritičku primjedbu. Jedna se odnosi na ipak poneko pretjerivanje u propisivanju sastavljenoga pisanja, osobito u pisanju složenih rednih brojeva (npr. milijuntisućusedamstošezdesetsedmi); druga se tiče Općega pravopisnog rječnika, koji je previše opterećen rijetkim turcizmima, ali i nekim "folklornim" riječima koje "prosječnom korisniku Pravopisa jedva da mogu zatrebati”, dok su zapostavljene "mnoge novije pravopisno obilježene riječi (posebice novije posuđenice iz engleskog)" (1993: 112). Ne propušta napokon Pranjković spomenuti i društveno-politički kontekst u kojemu je knjiga objavljena: spominje muke s naslovom, naime imenom jezika u njemu, a potom is negativnom recepcijom pravopisa, naročito u pojedinim beogradskim glasilima.

Međutim druge su dvije pravopisne knjige dobile izrazito negativne Pranjkovićeve ocjene. Prvo, osvrćući se na Osnove pravilnoga pisanja

1 Ovdje se navodi prema tekstu objavljenome u knjizi. 
Domagoja Grečla Pranjković će već u prvoj rečenici konstatirati da se o “"novom pravopisu' [navodnici u izvorniku, nap. L. B.] [...] malo [...] što, nažalost, može reći dobroga" (Pranjković 1997b: 43). ${ }^{2}$ Slijedi obrazloženje utemeljeno u pet točaka. ${ }^{3}$ Za novo pak izdanje Babić-Finka-Moguševa Hrvatskoga pravopisa - a bilo je to, podsjetimo, prvo nakon pretiska izdanja iz 1971. godine - odmah će reći da "izaziva u stručnoj javnosti, a i uopće među korisnicima priličan broj nedoumica" pa će se kao jedan od onih "koje mnoga rješenja autora pravopisa [...] iznenađuju, zbunjuju i/ili ne zadovoljavaju" smatrati "dužnim iznijeti svoje mišljenje i o pojedinim rješenjima i o Pravopisu u cjelini”" (Pranjković 1997b: 60). ${ }^{4}$ Popis je prigovora dugačak (recenzija je objavljena čak na deset stranica "Republike") i nećemo se ovdje na njih pojedinačno osvrtati; reći ćemo tek da se svi mogu podvesti pod polazišnu napomenu: "[...] u Pravopisu ima previše formulacija koje su neprecizne, nejasne ili posve nerazumljive" (1997b: 60). Nakon temeljite argumentacije slijedi i konačna ocjena:

Na temelju svega što je rečeno moram ustvrditi da Hrvatski pravopis S. Babića, B. Finke i M. Moguša (izdanje iz 1994. godine) nije zaslužio prolazne ocjene. Previše je naime u njemu pravopisnih pravila koja su ili nelogična, ili loše formulirana, ili nedosljedna, ili nepotpuna, ili suvišna, ili previše 'rastezljiva', pa nepotrebno destabiliziraju ustaljenu normu, a u pravopisnom rječniku ima previše elemenata koji mu ni po čemu ne pripadaju. To je moje mišljenje, koje, naravno, nikoga ne obvezuje. Je li ono i, ako jest, u kojoj mjeri utemeljeno, neka prosude čitatelji ovoga osvrta te sadašnji i budući korisnici Pravopisa (1997b: 73-74).

Konačno, vjerojatno nas ne bi trebalo iznenaditi da su navedena dva negativno intonirana prikaza ubrzo prepoznata kao okidač za polemičke dijaloge između prozvanih autorā (D. Grečla i S. Babića) i ocjenitelja njihovih normativnih uradaka (o tome usp. u Pranjković 1997b: 47-49; 74-96 te u Pranjković 2008: 22-28).

2 Ovdje se navodi prema tekstu objavljenome u knjizi.

3 Ilustracije radi navest ćemo samo konstatacije iz prve i pete točke: "1. Knjiga se temelji na nekorektnom, a jednim dijelom i neznalačkom prepisivanju Anić-Silićeva Pravopisnog priručnika"; "5. Iz svega rečenog proizlazi da se Grečlova knjiga može okarakterizirati kao površno i nestručno pisan, pa već i zbog toga nepotreban, "mali školski pravopis"' (Pranjković 1997: 43 i 48). Ilustracija je to i Pranjkovićeve retoričke strategije: na samom početku odmah zauzima jasan stav, potom ga navodeći primjere obrazlaže i potkrepljuje da bi u zaključku poentirao.

4 Ovdje se navodi prema tekstu objavljenome u knjizi. 
Četvrti pravopis o kojemu je Pranjković pisao Hrvatski je pravopis Franje Cipre i Adolfa Bratoljuba Klaića, prvi put objavljen 1944. godine. Povod za pisanje o knjizi staroj gotovo pola stoljeća bila je pojava njezina pretiska 1992. godine, što je autor bez ograde ocijenio dobrim izdavačkim potezom. Naizgled neaktualnu temu Pranjković je znao aktualizirati. Obrazlažući načela tzv. korienskoga pravopisa, naime pretežito morfonološkoga, i upozoravajući na probleme s kojima su se svojedobno suočavali korisnici u nastojanju da pišu po njegovim pravilima, jasnu poruku odašilje pobornicima takva pisanja (i uopće jezičnim čistuncima) u devedesetima. Pojavljivanje ovog pravopisa, kaže, "ne bi smjelo značiti da bi ga trebalo propisati za upotrebu ili da bi trebalo raditi novi pravopis koji bi se zasnivao na temeljnim načelima (prije svega morfonološkom) koja su u njemu primijenjena" te dodaje i ovo:

Uostalom, neosporno je da je pravopis na morfonološkom načelu kao temeljnom slabo funkcionirao i u onom kratkom periodu u kojem je bio na snazi, a prije (1892-1942) i poslije toga perioda (1945-1993) po pola je stoljeća kontinuirane tradicije fonološkog pisanja u Hrvata. Nema nijednog iole ozbiljnijeg razloga da se taj kontinuitet (ponovo) prekida (Pranjković 1993a: 177, 178).

$* * *$

Sljedeću skupinu Pranjkovićevih tekstova pravopisne tematike teško je podvesti pod zajednički nazivnik. Ima među njima i novinskih kolumni, i polemičkih utuka, ${ }^{5}$ ali i znanstvenih ili stručnih članaka i kongresnih priopćenja. Ovdje ćemo izdvojiti samo glavne teme i glavne naglaske (slijedeći kombinaciju kronološkog i tematskog kriterija).

Konkretan povod za pisanje teksta koji je redakcija tjednika "Danas" naslovila Na Prokrustovoj postelji (Pranjković 1992) bio je dopis koji je Jezično povjerenstvo Matice hrvatske krajem 1992. godine uputilo većem broju kulturnih, znanstvenih i državnih ustanova. Dopisom znakovita, svakako i tendenciozna naslova - Načela za usavršavanje hrvatskoga pravopisa - željelo se, kratko rečeno, sugerirati poželjnost, čak i nužnost radikalnijih promjena (točnije i u krajnjoj konsekvenci: morfonologizacije) hrvatske pravopisne norme. Pranjković o sadržaju toga dokumenta obavještava javnost,

5 Polemičke utuke ne navodimo kao zasebne jedinice u popisu izvora i literature. Upućujemo naime na dvije knjige Pranjkovićevih polemika $(1997,2008)$ u kojima su objavljeni uz nužnu kontekstualizaciju. 
koja bi, veli, "morala biti obaviještena o tome što je čeka ako se predložena rješenja prihvate" te nedvosmisleno upozorava da bi u tom slučaju pravopisna zbrka mogla biti i veća od trenutne (Pranjković 1997b: 51). ${ }^{6}$ Podsjetimo (jer pomoći će nam to da bolje shvatimo razloge Pranjkovićeva otpora i uopće žestine njegove reakcije), riječ je bila o četirima "načelima" (ovdje ih navodimo sažeto): prvo se ticalo pisanja nekadašnjega jata i predlagalo se pisanje $i e$ u dugim slogovima (biel, snieg) te pisanje je iza tzv. pokrivenoga $r$ (strjelica, brježuljak); drugi je prijedlog bio da se $d$ i $t$ pišu u oblicima imenica na -tak, $-d a k,-t a c,-d a c,-t k a$ ispred $c$ i $c$ te u tvorbi riječi ispred sufikasa koji počinju sa $c$ ili č (mladca, mlatca, zadatci, pripovietci; govedče, sirotče); treće je bilo pitanje fonološki ili morfonološki pravopis, a četvrto treba li ili ne treba pisati $j$ u oblicima imenica koje završavaju na $i$ (Leopardia ili Leopardija). Za razliku od Povjerenstva, koje svoje prijedloge nije posebno argumentiralo, Pranjković razloge svoga protivljenja prvim trima predloženim promjenama jasno obrazlaže (jedino četvrta točka, po njemu, sadrži utemeljenu dilemu). Odlučno se naime protivi izmišljanju problema ondje gdje ih objektivno nema, ali i jeftinoj politizaciji jezika i pravopisa. Ovoj se temi (naime dopisu Jezičnoga povjerenstva) autor još jednom vratio - u priopćenju na Četvrtom hrvatskom slavističkom kongresu kad je govoreći o hrvatskoj pravopisnoj normi u zadnjemu desetljeću 20. stoljeća težište stavio upravo na zbivanja koja su prethodila drugome izdanju Babić-Finka-Moguševa Hrvatskoga pravopisa (usp. Pranjković 2006).

Problematici tzv. dugoga jata i zamisli Dalibora Brozovića da se u dugim slogovima s jatom piše ie (diete umjesto dijete) usprotivio se Pranjković u dvama svojim tekstovima - Je li dugi refleks jata fonem ili morfonem (1997a) objavljen je u časopisu "Jezik", a drugi, Odgovori na Brozovićeva pitanja (1999) u "Vijencu" Matice hrvatske. U potonjem odgovoru Brozoviću (1999) Pranjković je popisao argumente protiv pisanja ie na poziciji tzv. dugoga jata, i sve to kao odgovor na polemički intonirana Brozovićeva pitanja koja su trebala ići u prilog upravo novopredlaganom pravopisnom rješenju. Pritom na konkretan Brozovićev upit kako bi trebalo riješiti opreku između sekvence /i/j/e/(npr. u pijemo) i tzv. dugoga refleksa jata kakav se susreće u riječima i oblicima tipa mlijeko Pranjković spremno uzvraća: "Opreka svakako postoji (moglo bi se doduše raspravljati o tome je li to fonološka opreka ili nije, ${ }^{7}$ ali

6 Ovdje se navodi prema tekstu objavljenome u knjizi.

7 O toj će problematici ubrzo biti riječi u tekstu o kojemu je riječ u nastavku. 
u takve dvojbe ovdje nije primjereno ulaziti), ali nije nužno da se ona izrazi pravopisno (niti slovopisno), pa zato predlažem da se u uobičajeno pisanje dugoga jata ne dira, a ako bi se kojim slučajem i diralo, ponavljam prijedlog da se piše kaoje, a ne kao ie" (Pranjković 2008: 11). ${ }^{8}$ Ne ostaje međutim sve na toj konstataciji - Pranjković pregledno i sustavno navodi sedam razloga (točke od $a$ do $g$ ) koji idu u prilog njegovu uvjerenju! Ništa manje temeljit - i odlučan - nije Pranjković u tekstu o fonološkom ili morfonološkom statusu jata (1997a). Iako objavljen u znanstvenom časopisu, prilog je eksplicitna polemika (tj. polemički utuk). Razglabajući Brozovićev odgovor na neke ranije svoje napise u kojima je problematizirao fonološki status dugoga jata ili tzv. dvoglasnika (a upravo je to mišljenje koje je zastupao Brozović), nakon što je upozorio na slabe točke Brozovićeva utuka, konstatira da se dalje neće "osvrtati na ostale Brozovićeve 'argumente' ovoga tipa", nego će "prijeći na bitno, a bitno je to" - opet će Pranjković biti nedvosmislen - da on "nikako ne smatra[m] da je 'dvoglasnik ie' poseban fonem" (Pranjković 2008: 16). ${ }^{9}$ Nakon te tvrdnje - očekujemo već od Pranjkovića takvu retoričku strategiju - slijedi argumentacija sustavno razložena u osam točaka (točnije, osma je točka posvećena vrlo uvjerljivu tumačenju morfonološkoga statusa jata). Ovdje se, dakako, nećemo dalje baviti tom tematikom, bez obzira na činjenicu da sam prijepor - evidentno je - ima sasvim izravne reperkusije na različita pravopisna rješenja za koja se suprotstavljene strane zalažu. Istaknut ćemo međutim nešto drugo. Argumentacija koju je Pranjković upotrijebio u obrani vlastitoga stava u teorijskome je i metodološkome smislu uzorna. Možemo, dakako, samo spekulirati o tome koliko je konkretan polemički okršaj pridonio jezgrovito, sustavno i jasno obrazloženim stavovima.

Znatno je smireniji Pranjkovićev tekst Opća načela sastavljenoga i nesastavljenoga pisanja. Tekstom objavljenim u tematskom broju časopisa "Dometi” (tema: "Hrvatski pravopis 1892-2002”) autor načinje "jedno od najkompliciranijih, pa zato i trajno aktualnih pravopisnih pitanja" (Pranjković 2002: 61). Posebna je vrijednost tog priloga u sustavnom pregledu načela zastupljenih u hrvatskoj ne samo pravopisnoj nego i gramatičkoj tradiciji (posebno u Hrvatskome pravopisu Ivana Broza i potom u studiji Augusta Musića “Koje se riječi u hrvatskom pišu zajedno”). Aktualnost teme Pranjković će dodatno naglasiti u zaključku: "Aktualni se pravopisi

\footnotetext{
Ovdje se navodi prema tekstu objavljenome u knjizi.
}

9 Ovdje se navodi prema tekstu objavljenome u knjizi. 
hrvatskoga standardnog jezika izrazito razlikuju s obzirom na temeljna polazišta sastavljenoga i nesastavljenoga pisanja (u konkretnim rješenjima, npr. u pravopisnim rječnicima, razlike i nisu osobito brojne)" (2002: 61). Završna je poruka jasna: pitanjem će se sastavljenoga i nesastavljenoga pisanja morati ozbiljno baviti i budući hrvatski pravopisci.

Iako bi se uvidom u Pranjkovićevu bibliografiju moglo pomisliti da smo ovime stigli do kraja popisa njegovih tekstova o pravopisnoj problematici, spomenut ćemo ipak još jedan. Riječ je o članku sintetske naravi Normativne i paranormativne inovacije $\mathrm{u}$ hrvatskome jeziku, ${ }^{10} \mathrm{u}$ kojemu se - također sintetski, ujedno i kritički - prikazuju i (para)normativne inovacije u hrvatskoj pravopisnoj normi u devedesetim godinama 20. stoljeća (usp. Pranjković 2008: 84-86).

\section{PRANJKOVIĆEVI PRAVOPISNI NAZORI}

Ovaj kroki Pranjkovićeva pisanja o pravopisu zaokružit ćemo pokušajem isticanja njegovih pravopisnih nazora. Jedno je naime sigurno - u svakom retku ovdje komentiranih tekstova razabire se autorovo gledište; često zaoštren ton svjedoči ne samo o njegovoj angažiranosti nego i o istinskoj zainteresiranosti za teme o kojima piše. To nesumnjivo olakšava i rezime poput ovoga:

1. Pravopis mora biti dosljedan, logičan i jasan. To vrijedi i za pravopis $\mathrm{u}$ cjelini i za pojedina pravopisna pravila, koja moraju biti u skladu s odabranim pravopisnim načelom/pravopisnim načelima.

2. Za pravopis (i uopće za pismenost) važna je tradicija. To je osnovni razlog zbog kojega se energično suprotstavlja svakoj ideji radikalnih promjena u pravopisu.

3. U pravopisnu normu treba intervenirati samo ondje gdje postoje realni problemi u pisanju, a oni su u onim pravopisnim rješenjima u čijoj provedbi korisnici često griješe. Ne treba dakle izmišljati pravopisne probleme i novim rješenjima dodatno zbunjivati javnost te, u konačnici, destabilizirati pravopisnu normu.

10 Tekst je prvo objavljen na njemačkome jeziku - Normative und paranormative Neuerungen in der kroatischen Sprache - u zborniku Die Sprache Südeuropas heute, ur. Barbara Kunzmann Müller (Peter Lang, Berlin, 2000), a potom i na hrvatskome u zadarskom zborniku (usp. Pranjković 2001). Ovdje se upućuje na hrvatski tekst objavljen u knjizi (Pranjković 2008). 
4. Naposljetku, ne manje važno, pravopisni priručnik mora biti u najvećoj mogućoj mjeri oslobođen od svega nepravopisnoga. To osobito vrijedi za njegov rječnički dio, koji nikako ne smije normirati leksik, ne smije biti ni jezični savjetnik te ni na koji način sugerirati leksički odabir.

\section{PRANJKOVIĆ KAO POLEMIČAR}

Nesumnjivo, pozornosti je vrijedan podatak da većinu Pranjkovićevih tekstova o pravopisnim temama nalazimo u dvjema knjigama njegovih sabranih polemika. O tim je polemikama međutim već bilo riječi (usp. Badurina 2010). Ovom će se prigodom u središtu našega zanimanja naći jedno drugo pitanje: u kojim će se značajkama autorovih tekstova o pravopisnim temama prepoznavati indikatori polemičnosti, odnosno okidači za polemičke utuke koji su ih nerijetko pratili? Naime bez obzira na činjenicu što je pravopis kao tema sam po sebi društveno aktualan i/ili intrigantan, ne može se ne zamijetiti da su Pranjkovićevi tekstovi u tom smislu posebno potentni. Drugim riječima, za neka će se obilježja Pranjkovićeva stila - vjerujemo - moći utvrditi ne samo da su provocirala polemičke dijaloge nego da su kao takva i pokazatelji autorove polemičnosti.

U obzir ovdje uzimamo jedan Pranjkovićev tekst - prikaz novoga izdanja Babić-Finka-Moguševa Hrvatskoga pravopisa iz 1994. godine (usp. Pranjković 1995). Riječ je dakle o prikazu novoobjavljene knjige, ne o (primarno) polemičkom tekstu! Ono međutim za čim u ovom tekstu tragamo nalazimo već u prvim ispisanim recima. Ponajprije autor se ne libi iznošenja vlastitih stavova, i kao takve ih izrijekom predstavlja: "Kako sam i sam među onima koje mnoga rješenja autora Pravopisa, akademikā Stjepana Babića, Božidara Finke i Milana Moguša iznenađuju, zbunjuju i/ili ne zadovoljavaju, smatram se dužnim iznijeti svoje mišljenje i o pojedinim rješenjima i o Pravopisu u cjelini" (usp. Pranjković 1997b: 60, istakla L. B.) ${ }^{11}$ Potom - ne manje važne - i Pranjkovićeve su gradirane (dis)kvalifikacije prikazivanog djela, odnosno rješenjā njime propisanih: ona ne samo da iznenađuju i zbunjuju

11 Slično će i završiti tekst: "To je moje mišljenje, koje, naravno, nikoga ne obvezuje" te će, štoviše, u nastavku dodatno čitatelje p(r)ozvati na dijalog - "Je li ono i, ako jest, u kojoj mjeri utemeljeno, neka prosude čitatelji ovoga osvrta te sadašnji i budući korisnici Pravopisa" (usp. Pranjković 1997b: 74, istakla L. B.). 
nego i ne zadovoljavaju! $!^{12}$ Naposljetku (iako smo od toga mogli i krenuti) već je u naslovu prikaza - Pravopis koji zbunjuje - najavljeno nezadovoljstvo autora prikaza objavljenim djelom. I, naravno, kako negativne kritike prije pobuđuju reakcije negoli pozitivne, ne bi nas trebala iznenaditi reakcija jednoga od autorā Pravopisa, a potom i Pranjkovićev još žešći odgovor. Slikovito rečeno, nakon ipak prilično blage ocjene "pravopis koji zbunjuje" slijedi mnogo drastičnija procjena da razmatrana knjiga "vrlo ozbiljno konkurira za najlošiju normativnu knjigu u povijesti hrvatske ortografije" (usp. Pranjković 2008: 28). Očito je, u polemičkom okršaju na snagu stupaju zakonitosti toga žanra (više o polemici usp. u Badurina 2010 te Badurina-Palašić 2016).

I dok naglašenu subjektivnost i (implicitnu, gdjekad i eksplicitnu) dijalogičnost možemo smatrati indikatorima polemičnosti, ${ }^{13}$ postavlja se pitanje u kakvu su odnosu te značajke Pranjkovićevih tekstova spram očekivanih i/ili poželjnih obilježja komunikacije u znanosti. U odgovoru na nj morat ćemo se suočiti s dijelom različitim pristupima problematici jezika znanosti. I dok s jedne strane danas već klasična funkcionalna stilistika znanstveni funkcionalni stil određuje kao dominantno objektivan i apstraktan, što se mora očitovati i u jezičnim značajkama tekstova koji mu pripadaju, ${ }^{14}$ novija kritička analiza diskursa i kritička stilistika polaze od postulata da nema nevinog izbora diskursa, pa onda ni neutralne pozicije znanstvenika. ${ }^{15}$ Imajući nadalje na umu žanrovsku polivalentnost akademskog diskursa, ali i brojna međudiskursna pretapanja, naći ćemo uporišta i za naša nastojanja da polemičke tekstove sagledamo ne više $u$ (navodnom) sukobu sa znanstvenim funkcionalnim stilom, nego, naprotiv, kad je o polemikama o znanstvenim

12 Budući da je riječ o pravopisu - čija bi rješenja trebala biti logična, jasna, jednoznačna i samim time lako pamtljiva - sasvim je jasno da je prikazivačeva ocjena, koja će u nastavku biti i dodatno obrazložena, nedvosmisleno negativna.

13 Uza sve to ne možemo zanemariti Pranjkovićevu odlučnost u iskazivanju vlastitih stavova: $u$ tom smislu ne ostavlja on prostora za pregovaranje (dakle dijalog), u čemu smo prepoznali specifičnost upravo polemičkog dijaloga (usp. Badurina 2010: 70-71).

14 Reprezentativan je opis znanstvenog funkcionalnog stila onaj iz pera Josipa Silića (usp. Silić 2006: 43-64). Valja međutim upozoriti i na to da u interpretacijama i primjeni te teorije nerijetko ima plošnosti i zastranjenja. U tom kontekstu pozornosti je vrijedno (novije) zapažanje da u znanstvenome tekstu ne treba izbjegavati ekspresivnost, koju, dodaje se, valja razlikovati od emocionalnosti (usp. Silić 2006: 192).

$15 \mathrm{O}$ toposu naglašene subjektivnosti u znanstvenom tekstu - naspram toposu afektirane skromnosti i toposu afektirane objektivnosti - piše Marina Katnić-Bakaršić (2012: 71; o akademskom diskursu v. 67-90). 
pitanjima riječ, upravo u kontekstu znanosti i znanstvenog/akademskog diskursa (usp. Badurina 2010: 82, Užarević 2012: 233).

Jedno je, smatramo, neupitno. Pranjković je u svojim tekstovima o pravopisnim temama kritički i/ili polemički razmatrajući načelna i konkretna pitanja hrvatskoga pravopisa te napose izravno se sučeljavajući s neistomišljenicima pokazao kako se dobro utemeljenom (pa i efektnom) argumentacijom otvaraju, problematiziraju i bistre važna pitanja hrvatske pravopismenosti. Iako on i nije jedini koji je u proteklim desetljećima pratio zbivanja u vezi s hrvatskim pravopisom i o njima pisao, sigurno je jedinstven po energiji i žestini koje je unosio u svoje tekstove. Ovako je Užarević (2012: 233) opisao jedan tip znanstvenika iz kojih se, po njemu, regrutiraju polemičari: "U znanosti postoji poseban tip ljudi koji se odlikuju bujnim temperamentom, odrješitošću i beskompromisnošću u izlaganju stavova, težnjom da svaku spoznajnu situaciju zaoštre do krajnosti." Nije li to dobar kroki Pranjkovića znanstvenika?

\section{IZVORI I LITERATURA}

Badurina, Lada. 2010. Polemičnost i polemike Ive Pranjkovića. Jezična skladanja: Zbornik o šezdesetogodišnjici prof. dr. Ive Pranjkovića, ur. Lada Badurina i Vine Mihaljević, Udruga đaka Franjevačke klasične gimnazije Visoko - Zagreb, Zagreb, str. 69-83.

Badurina, Lada i Nikolina Palašić. 2016. Tekst protiv teksta: O argumentaciji u polemičkom diskursu. Riječki filološki dani 10, zbornik radova, ur. Lada Badurina. Filozofski fakultet u Rijeci, Rijeka, str. 267-279.

Katnić-Bakaršić, Marina. 2012. Između diskursa moći i moći diskursa. Zagreb: Naklada Zoro.

Pranjković, Ivo. 1987a. Prevarena očekivanja: Domagoj Grečl, Osnove pravilnoga pisanja, Zadružna štampa, Zagreb, 1987, “Oko”, br. 408, 5-19. studenoga, Zagreb, str. 10 [također u Ivo Pranjković, Jezikoslovna sporenja, Zagreb: Konzor, 1997, str. 43-46].

Pranjković, Ivo. 1987b. Uzoran priručnik: Vladimir Anić i Josip Silić, Pravopisni priručnik hrvatskoga ili srpskoga jezika, Sveučilišna naklada Liber i Školska knjiga, Zagreb 1986. "Vjesnik", 17. siječnja, str. 7 [također u I. Pranjković, Kronika hrvatskoga jezikoslovlja, Matica hrvatska, Zagreb, 1993, str. 106-112].

Pranjković, Ivo. 1992. Na Prokrustovoj postelji, "Danas", nova serija (probni dvobroj), 25. prosinca, str. 75-76 [također u I. Pranjković, Jezikoslovna sporenja, Zagreb: Konzor, 1997, str. 51-57].

Pranjković, Ivo. 1993a. Koriensko pisanje i novi hrvatski pravopis: Franjo Cipra i Adolf Bratoljub Klaić, Hrvatski pravopis, Zagreb, 1944; pretisak Hrvatska sveučilišna naklada, Zagreb, 1992, pogovor Stjepko Težak, str. $451+12$ nepag., u: I. Pranjković, Kronika hrvatskoga jezikoslovlja, Zagreb: Matica hrvatska, 1993, str. 172-178. 
Pranjković, Ivo. 1993b. Kronika hrvatskoga jezikoslovlja, Zagreb: Matica hrvatska.

Pranjković, Ivo. 1995. Pravopis koji zbunjuje: Stjepan Babić, Božidar Finka i Milan Moguš, Hrvatski pravopis, Školska knjiga, Zagreb, 1994. "Republika”, LI/5-6, 1995, str. 184-193 [također u I. Pranjković, Jezikoslovna sporenja, Zagreb: Konzor, 1997, str. 60-74].

Pranjković, Ivo. 1997a. Je li dugi refleks jata fonem ili morfonem. "Jezik", 45/5, 1998, str. 192-195 24 [također u I. Pranjković, Sučeljavanja: Polemički dueli oko hrvatskoga jezika i pravopisa, Zagreb: Disput, 2008, str. 14-18].

Pranjković, Ivo. 1997b. Jezikoslovna sporenja, Zagreb: Konzor.

Pranjković, Ivo. 1999. Odgovori na Brozovićeva pitanja. "Vijenac", VII, br. 136, 20. svibnja, str. 24 [također u I. Pranjković, Sučeljavanja: Polemički dueli oko hrvatskoga jezika i pravopisa, Zagreb: Disput, 2008, str. 10-14].

Pranjković, Ivo. 2001. Normativne i paranormativne inovacije u hrvatskome jeziku. Dani hrvatskoga jezika 2000 (zbornik), Matica hrvatska, Zadar, str. 23-33 [također u I. Pranjković, Sučeljavanja: Polemički dueli oko hrvatskoga jezika i pravopisa, Zagreb: Disput, 2008, str. 84-93].

Pranjković, Ivo. 2002. Opća načela sastavljenoga i nesastavljenoga pisanja. "Dometi”, 12/I-IV, Matica hrvatska, Ogranak u Rijeci, Rijeka, str. 53-62 [također u I. Pranjković, Ogledi o jezičnoj pravilnosti, Zagreb: Disput, 2010: 25-36, str. 106-112].

Pranjković, Ivo. 2006. Hrvatska pravopisna norma u zadnjem desetljeću 20. stoljeća. Četvrti hrvatski slavistički kongres: Uvodna predavanja, Varaždin - Čakovec, str. 47-62 [također u I. Pranjković, Sučeljavanja: Polemički dueli oko hrvatskoga jezika i pravopisa, Zagreb: Disput, 2008, str. 39-51].

Pranjković, Ivo. 2008. Sučeljavanja: Polemički dueli oko hrvatskoga jezika i pravopisa, Zagreb: Disput.

Pranjković, Ivo. 2010. Ogledi o jezičnoj pravilnosti, Zagreb: Disput.

Silić, Josip. 2006. Funkcionalni stilovi hrvatskoga jezika, Zagreb: Disput.

Užarević, Josip. 2012. Polemika. u: J. Užarević, Književni minimalizam, Zagreb: Disput, 232-234.

\section{SUMMARY}

\section{PRANJKOVIĆ ON ORTHOGRAPHY}

Ivo Pranjković deals with orthography in many of his texts. Among these are some relatively neutral papers in which he examines particular orthographic issues, some critical reviews, but also some very sharp polemic responses. What all of them have in common are the author's clearly expressed attitudes and his consistent argumentation. This paper will, on the one hand, focus on the subject-matter of Pranjković's texts on orthography and his views on orthography, and on the other, on the characteristics of his style, especially on its polemic qualities.

Key words: Ivo Pranjković, orthography, polemics, scientific text, academic discourse 